\title{
Studies on Mechanisms of Hypocalcemia of Magnesium Depletion
}

\author{
Chilumula R. Reddy, Jack W. Coburn, David L. Hartenbower, \\ Robert M. Friedler, Arnold S. Brickman, Shaul G. Massry, and \\ JENIFER JOWSEY \\ From the Medical and Research Services, Veterans Administration Wadsworth \\ Hospital Center, Los Angeles 90073, the Departments of Medicine, Cedars- \\ Sinai Medical Center and the University of California Los Angeles School of \\ Medicine, Los Angeles, California 90024, and the Section of Orthopedic \\ Research, Mayo Clinic and Mayo Foundation, Rochester, Minnesota 55901
}

A в S T R A C T Studies were carried out to evaluate the mechanism of hypocalcemia in magnesium depletion. Day old chicks fed a magnesium deficient diet developed marked hypocalcemia, with a direct relation between serum calcium $(y)$ and magnesium $(x): y=2.68 x+4.24$, $r=0.84$ (both in $\mathrm{mg} / 100 \mathrm{ml}$ ). Injections of parathyroid extract that increased serum calcium $2-3 \mathrm{mg} / 100 \mathrm{ml}$ in normals had no effect in Mg-depleted birds. Very large dietary supplements of calcium or vitamin $\mathrm{D}_{3}$ increased mean serum calcium only from 5.3 to 7.7 and $7.8 \mathrm{mg} / 100$ $\mathrm{ml}$, respectively, while a normal magnesium diet for 3 days increased calcium from 5.3 to $9.9 \mathrm{mg} / 100 \mathrm{ml}$ despite absence of dietary calcium. Intestinal calcium transport, studied in vitro, and the calcium concentration of the carcass was significantly increased in magnesium-depleted chicks, making it unlikely that reduced intestinal absorption of calcium caused the hypocalcemia. In magnesium-deficient chicks, the bone content of magnesium was decreased by $74 \%$, the calcium content was unchanged, and the cortical thickness of bone was markedly increased. After 3 days of magnesium-repletion, cortical thickness was reduced with increased endosteal resorption. There was an increase in unmineralized osteoid tissue in the magnesium-depleted chicks. Para-

This work was presented in part before the Annual Meeting of the Federated Societies for Experimental Biology, Atlantic City, N. J., 15 April 1972, and the Annual Meeting of the Western Section, American Federation for Clinical Research, Carmel, Calif., 1 February 1973.

Dr. Hartenbower and Dr. Brickman are Research and Education Associates, Veterans Administration.

Dr. Massry is an Established Investigator, American Heart Association.

Received for publication 26 December 1972 and in revised form 10 August 1973. thyroid gland size and histology did not differ in magnesium-depleted and control birds. The results suggest that hypocalcemia develops due to altered equilibrium of calcium between extracellular fluid and bone, favoring increased net movement into the latter. Failure of parathyroid gland function could also exist, and unresponsiveness to parathyroid hormone ( $\mathrm{PTH})$ may also contribute to the hypocalcemia. However, failure of PTH action is probably due to the presence of excess osteoid tissue rather than a primary event leading to hypocalcemia.

\section{INTRODUCTION}

Hypocalcemia has been reported to be associated with magnesium depletion in a number of species, including rats fed a low calcium diet $(1,2)$, sheep (3), pigs (4), calves $(5,6)$, dogs $(7,8)$, monkeys $(9)$, and man $(10$ 14). The factors underlying the hypocalcemia have not been clearly delineated. Theoretically, this hypocalcemia could arise due to several factors. Reduced intestinal absorption of calcium due to magnesium depletion per se. or altered action of vitamin $\mathrm{D}$ could contribute to hypocalcemia. An abnormal relationship between the rate of calcium movement from extracellular fluid into bone and rate of its removal could also account for hypocalcemia. Such a phenomenon could be due to failure of production or release of parathyroid hormone or to reduced skeletal responsiveness to the action of the hormone, to skeletal resistance to the action of vitamin $D$, to increased action of calcitonin or to a primary change in the solubility or rate of growth or dissolution of bone crystal. Finally, it is also possible that magnesium de- 
pletion might be associataed with enhanced deposition of calcium in extraskeletal sites to account for the shift of calcium out of serum.

In the present study, a model of experimental magnesium depletion in the chick is described, and various factors which might be involved in the development of hypocalcemia were evaluated.

\section{METHODS}

White leghorn cockerels obtained 1 day after hatching (through courtesy of $\mathrm{H} \& \mathrm{~N}$ Hatchery, Inc., Riverside, Calif.) were housed in electric brooders. Chicks were chosen as experimental models because their diet can be controlled immediately after hatching, permitting the rapid development of magnesium depletion. In addition, chickens are known to be sensitive to parathyroid extract (15), thus providing a suitable model to evaluate responsiveness to the hormone. Furthermore, considerable information is available concerning calcium homeostasis in this species. They received a synthetic diet, modified from that of Fox and Briggs (16), and distilled water ad libitum. The diet, as originally described, contained $0.060 \%$ magnesium, an amount considered the optimal quantity needed by growing chicks $(16,17)$. With deletion of supplemental magnesium and calcium salts, the basic diet was found by analysis to contain $0.004 \%$ magnesium and $0.005 \%$ calcium. In preparation of certain diets discussed below, magnesium sulfate was added providing $0.010,0.020$, or $0.060 \%$ magnesium. Unless noted otherwise, the diets were supplemented to contain $1.2 \%$ calcium, an amount higher than the $0.7-0.8 \%$ usually provided, $0.8 \%$ phosphorus, and $80 \mathrm{IU}$ of vitamin $\mathrm{D}_{3}$ (cholecalciferol) $/ 100 \mathrm{~g}$.

For purposes of establishing the appropriate dietary magnesium for studying magnesium depletion in the fowl, preliminary experiments were carried out in groups of 20 24 chicks which received diets with no, $0.020 \%$ or $0.060 \%$ added magnesium. The chicks were weighed twice each week, and at the end of 1,2 , and $3 \mathrm{wk}$, five to eight birds were decapitated and blood samples were obtained in a manner described elsewhere (18). In the groups receiving normal magnesium diet $(0.060 \%)$, there was rapid growth (e.g. from $40 \mathrm{~g}$ at day one to $100 \mathrm{~g}$ on day 15) and serum magnesium increased from $1.63 \pm 0.02$ (mean $\pm S E$ ) at day one to $2.95 \pm 0.04 \mathrm{mg} / 100 \mathrm{ml}$ at $3 \mathrm{wk}$ of age (Fig. 1). In the group receiving no added magnesium, most birds lost weight during the first week and all died by 8-10 days. Serum magnesium decreased to $0.65 \pm 0.05 \mathrm{mg} / 100 \mathrm{ml}$ by 7-8 days. The chicks receiving $0.020 \%$ magnesium grew nearly as rapidly as controls; serum magnesium initially fell below the control value but then increased to reach normal levels by 3 wk. In all groups hypocalcemia developed when serum magnesium fell.

Thus, the preliminary observations indicated that there is a greater requirement for magnesium in the chick during the first week of life. Therefore, the protocol was modified so that a diet providing $0.020 \%$ magnesium was given during the first week and no magnesium was given during the second and third weeks. With this procedure, the birds grew satisfactorily and the survival rate was good, but severe hypomagnesemia consistently developed by 21 days (Fig. 1). This procedure was utilized to produce magnesium deficiency in all subsequent experiments, whereas control birds received a diet containing $0.060 \%$ magnesium throughout.

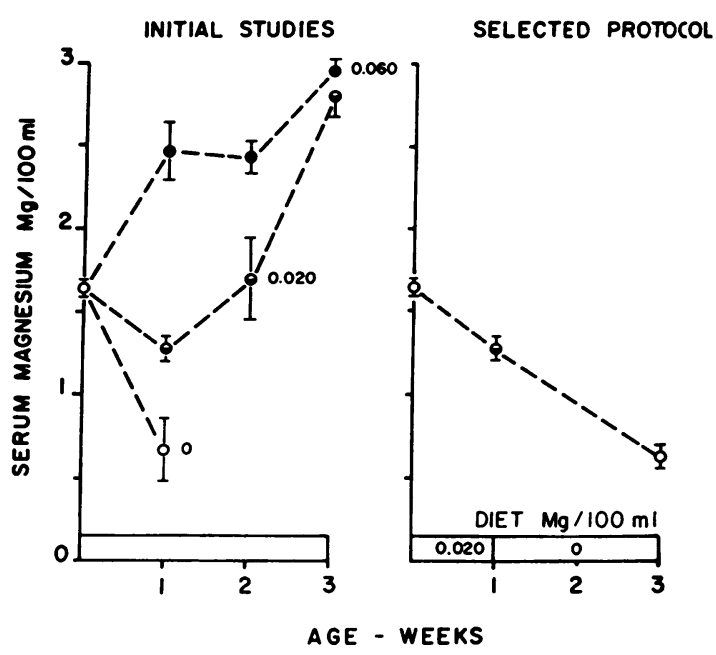

FIGURE 1 Effect of variations in dietary magnesium intake on serum magnesium according to the age of chicks. Results from initial studies, with groups of $7-10$ chicks receiving the same diet throughout, are shown on the left, while results with the usual protocol are given on the right. The figures indicate the percent magnesium in the diet. Values are mean $\pm S E M$.

All the studies were carried out when the chicks were 19-25 days of age. Experiments were performed to characterize the biochemical changes induced by magnesium depletion in serum and various tissues and to examine the factors underlying the development of hypocalcemia. Because of variability between groups of chicks obtained at different times, control birds receiving a normal magnesium diet $(0.060 \%)$ were always evaluated with each experiment of magnesium depletion, and comparisons were only made between such simultaneous observations. The studies included:

Tissue and carcass analysis. Immediately after decapitation, tissue samples of $200-300 \mathrm{mg}$ from heart, kidney, and skeletal muscles were obtained. Bone samples from the femur were cleaned of muscle and fascia; both epiphyseal ends were discarded, the shaft of the femur was split longitudinally, and the marrow was removed first by scraping with a scalpel and then by washing with a jet of distilled water. The various tissue samples were then dried at $105^{\circ} \mathrm{C}$ for 72-96 h, washed twice with ether for the extraction of fat, redried, and weighed. The fat-free dry samples were ashed in a muffle furnace at $560^{\circ} \mathrm{C}$ for $24 \mathrm{~h}$. The resultant ash was weighed and then dissolved in $3 \mathrm{~N} \mathrm{HCl}$ for subsequent biochemical analysis. To assess the total body content of minerals, the entire carcass, after the birds had been bled and the intestine removed, was analyzed for magnesium, calcium, and phosphorus in seven normal and seven magnesium-depleted chicks. The carcass was weighed immediately after sacrifice, dried at $105^{\circ} \mathrm{C}$ for $5-6$ days, reweighed; and then ashed and analyzed as described above for tissue samples.

Effect of dietary supplements of calcium, cholecalciferol, and magnesium in magnesium-depleted chicks. On days 19,20 , and 21 , groups of 8-10 magnesium-depleted chicks received one of the following supplements added to the usual magnesium depletion diet: (a) a mixture of $\mathrm{CaCO}_{\mathrm{s}}$ and $\mathrm{CaHPO}_{4}$, to provide either 3.6 or $12 \%$ calcium, $(b)$ 
TABLE I

Biochemical Observations in Serum of Magnesium-Depleted Chickens

\begin{tabular}{|c|c|c|c|c|c|c|}
\hline Experimental group & Magnesium & Calcium & Phosphorus & Sodium & Potassium & Uric acid \\
\hline & $\mathrm{mg} / 100 \mathrm{ml}$ & $\mathrm{mg} / 100 \mathrm{ml}$ & $\mathrm{mg} / 100 \mathrm{ml}$ & meq/liter & meq/liter & $\mathrm{mg} / 100 \mathrm{ml}$ \\
\hline Control & $\begin{array}{c}2.24 \pm 0.037 \\
(20)\end{array}$ & $\begin{array}{c}10.5 \pm 0.085 \\
(20)\end{array}$ & $\begin{array}{c}6.0 \pm 0.12 \\
(20)\end{array}$ & $\begin{array}{c}149 \pm 0.97 \\
(7)\end{array}$ & $\begin{array}{c}6.0 \pm 0.23 \\
(7)\end{array}$ & $\begin{array}{l}6.8 \pm 0.31 \\
(20)\end{array}$ \\
\hline Magnesium depletion & $\begin{array}{c}0.61 \pm 0.044^{*} \\
(17)\end{array}$ & $\begin{array}{l}5.8 \pm 0.200^{*} \\
(17)\end{array}$ & $\begin{array}{l}9.4 \pm 0.32^{*} \\
\quad(17)\end{array}$ & $\begin{array}{c}167 \pm 1.29^{*} \\
(16)\end{array}$ & $\begin{array}{l}4.7 \pm 0.21^{*} \\
(16)\end{array}$ & $\begin{array}{c}13.4 \pm 1.57^{*} \\
(17)\end{array}$ \\
\hline
\end{tabular}

All data are mean $\pm \mathrm{SE}$; the numbers in parenthesis indicate the number of animals in each group.

* Values differ from control, $P<0.001$. Because of insufficient quantities of serum, measurements of $\mathrm{Na}$ and $\mathrm{K}$ were not made in all samples.

cholecalciferol, to supply either 80,000 (2 mg) or 800,000 IU $(20 \mathrm{mg})$ of cholecalciferol per kilogram of diet; with the average daily quantity of feed consumed by these birds, the daily intake of cholecalciferol would be 800 and 8,000 IU/day per bird, respectively; (c) magnesium sulfate, to provide either 0.010 or $0.060 \%$ magnesium in the final diet with the calcium content either maintained at $1.2 \%$ or with all calcium salts deleted (designated $0 \% \mathrm{Ca}$ ). On day 22, after 3 days of altered diet, blood samples were obtained for the measurement of serum calcium and magnesium from these groups and from chicks which had followed the usual magnesium depletion protocol.

Effect of dietary restriction of phosphate. In order to evaluate whether the rise in serum phosphorus which was generally observed during magnesium depletion might be responsible for hypocalcemia, studies were carried out with the phosphate content of the magnesium-deficient diet reduced from 0.8 to $0.4 \%$.

Intestinal calcium transport. Intestinal transport of calcilm was studied in vitro as an index of intestinal absorption of calcium in the magnesium-depleted chicks. Immediately after decapitation, the segment of ileum just proximal to the yolk sac was excised, cleaned, and placed in ice-cold $0.15 \mathrm{M} \mathrm{NaCl}$; within $30 \mathrm{~min}$ the segment was opened longitudinally and mounted in a modified Ussing shortcircuit apparatus. The rates of movement of ${ }^{45} \mathrm{Ca}$ from the mucosal to serosal side and from the serosal to mucosal side were measured exactly as reported elsewhere (19) with a ${ }^{20} \mathrm{Ca}$ concentration of $0.10 \mathrm{mM}$. The rates of transport or flux $\left(J m \rightarrow s \text { or } J_{s} \rightarrow m\right)^{1}$ were determined by linear regression analysis of the rate of appearance of ${ }^{45} \mathrm{Ca}$ on the opposite side to which radiocalcium has been added and expressed as nanomoles per square centimeter per hour.

Response to exogenous parathyroid extract (PTE). The effect of exogenous parathyroid hormone on serum calcium was evaluated by the subcutaneous injection of PTE (Eli Lilly \& Co., Indianapolis, Ind.) in normal chicks, magnesium-depleted chicks, and those repleted with magnesium for 3-8 days. Doses of 50,100 , or $200 \mathrm{U}$ of PTE were given to the magnesium-depleted chicks while the normals received $100 \mathrm{U}$. All injections were given between 8 and 10 a.m. after the birds had been fasting for the previous $12 \mathrm{~h} .4 \mathrm{~h}$ after administration of PTE, blood samples were obtained for measurement of serum calcium. In part of these experiments, blood samples were also obtained before administration of PTE by cardiac puncture.

${ }^{1}$ Abbreviations used in this paper: $J m \rightarrow s, J s \rightarrow m$, rates of flux, mucosal to serosal and serosal to mucosal, respectively; PTE, parathyroid extract; $\mathrm{PTH}$, parathyroid hormone.
Microradiographic evaluation of bone. In eight magnesium-depleted birds and seven chicks which had been repleted with magnesium for 3 days as described above, the femurs were obtained at the time of decapitation, fixed in $70 \%$ ethanol, and evaluated by quantitative microradiography in a manner described elsewhere (20).

Biochemical methods. Measurements of calcium, magnesium, phosphorus, uric acid, sodium, and potassium were made by methods previously reported $(18,21)$. For the determination of protein-bound and diffusible calcium concentrations in plasma, heparinized blood samples were obtained from the abdominal aorta of control and magnesiumdepleted chicks, and ultrafiltrates of plasma were prepared in Lavietes chambers by anaerobic ultrafiltration in a manner previously described (21). Total serum solids, used as indices of serum protein concentration, were determined by refractometry (Goldberg Refractometer, American Optical Corp., Buffalo, N. Y.).

Histologic evaluation. In four to five magnesium depleted and four to five control birds, kidney tissue, and parathyroid glands obtained at the time of sacrifice, were fixed in $10 \%$ formalin; histological sections were prepared stained with hematoxylin and eosin, and examined by light microscopy.

\section{RESULTS}

The effects of magnesium depletion on serum electrolytes are given in Table I. With the development of magnesium deficiency, there was a fall in serum calcium to levels of $3-7 \mathrm{mg} / 100 \mathrm{ml}$, with a direct correlation between the levels of serum calcium and those of magnesium (Fig. 2). The percent diffusibility of calcium in magnesium-depleted chicks was 64.7 and 70.1 in controls. There was also a significant decrease in the level of serum potassium and increases in concentrations of sodium, phosphorus, and uric acid. The hematocrit was lower in the magnesium-depleted chicks, 27 vs. 33 vol \%; but there were no differences in serum protein concentrations. The effect of restriction of dietary phosphate on the hypocalcemia is shown in Fig. 3. With use of the phosphate-restricted, magnesium-deficient diet, serum phosphorus level was not different from control; however, significant hypocalcemia $(7.12 \pm 0.21 \mathrm{mg} / 100 \mathrm{ml})$ still developed.

The effects of magnesium depletion on the content of 


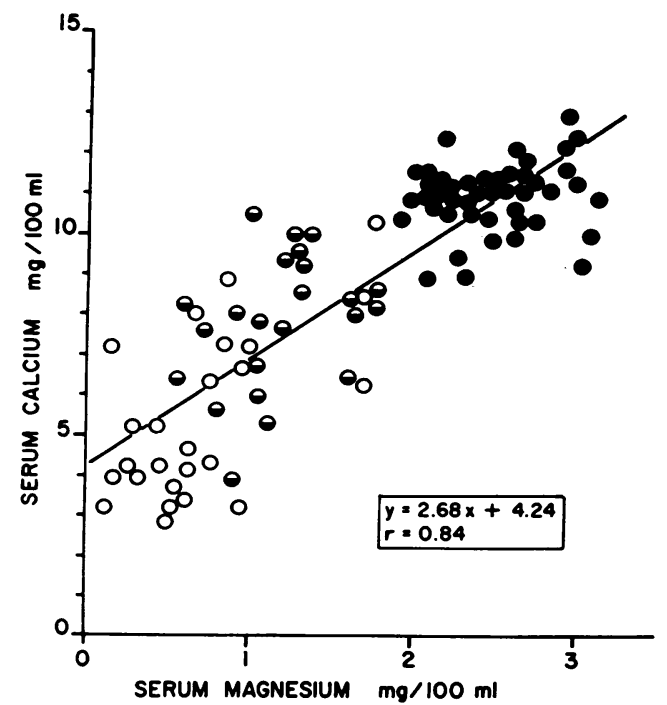

FIGURE 2 Relation between serum calcium concentration and that of magnesium in chicks receiving either a normal magnesium diet $(0.060 \%)(\bullet)$, the usual magnesium depletion requires as described in the text $(O)$, or maintained on 0.010 or $0.020 \%$ magnesium throughout the study (Q). Each point represents the values in an individual chick.

electrolytes in kidney, skeletal muscle, heart and bone are shown in Table II. The bone content of magnesium was markedly decreased to $26 \%$ of control in the depleted

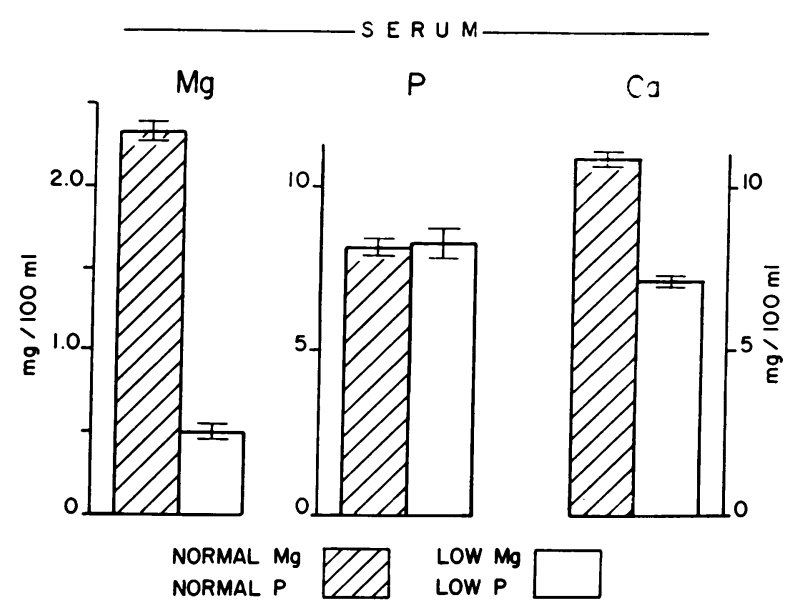

Figure 3 The effect of dietary restriction of both magnesium and phosphate on serum levels of calcium, magnesium, and phosphorus. Each group contains seven to nine chicks; values are mean \pm SEM.

birds, while the magnesium concentrations of other tissues were either unchanged (skeletal muscle and kidney) or only slightly reduced (heart). The calcium content was not significantly different in any of the tissues studied. The content of sodium in bone increased while that of potassium was reduced. The content of magnesium in the carcass was lower in the magnesium-depleted birds while concentrations of calcium and phosphorus were

TABLE II

Electrolyte Content of Various Tissues in Magnesium-Depleted Chicks

\begin{tabular}{|c|c|c|c|c|c|}
\hline & & Kidney & Muscle & Heart & Bone \\
\hline $\begin{array}{l}\text { Magnesium } \\
\text { (mg/100 g) }\end{array}$ & $\mathrm{E}$ & $\begin{array}{c}80.3 \pm 2.19 \\
(10) \\
79.0 \pm 1.66 \\
(9)\end{array}$ & $\begin{array}{c}111 \pm 2.10 \\
(28) \\
113 \pm 3.07 \\
(21)\end{array}$ & $\begin{array}{c}84.3 \pm 1.43 \\
(10) \\
79.8 \pm 1.22^{*} \\
(9)\end{array}$ & $\begin{array}{c}355 \pm 0.86 \\
(10) \\
92 \pm 1.48 \ddagger \\
(9)\end{array}$ \\
\hline $\begin{array}{l}\text { Calcium } \\
\qquad(\mathrm{mg} / 100 \mathrm{~g})\end{array}$ & $\begin{array}{l}\mathrm{C} \\
\mathrm{E}\end{array}$ & $\begin{array}{c}72.2 \pm 6.22 \\
(8) \\
55.2 \pm 5.48 \\
(7)\end{array}$ & $\begin{array}{c}17.4 \pm 1.21 \\
(28) \\
17.5 \pm 1.14 \\
(21)\end{array}$ & $\begin{array}{c}47.2 \pm 4.18 \\
(10) \\
49.3 \pm 8.50 \\
\quad(9)\end{array}$ & $\begin{array}{c}26270 \pm 400 \\
(10) \\
26780 \pm 470 \\
(9)\end{array}$ \\
\hline $\begin{array}{l}\text { Sodium } \\
\quad(\mathrm{meq} / 100 \mathrm{~g})\end{array}$ & $\begin{array}{l}C \\
E\end{array}$ & $\begin{array}{c}41.9 \pm 1.604 \\
(10) \\
40.8 \pm 1.896 \\
(9)\end{array}$ & $\begin{array}{c}12.6 \pm 0.474 \\
(28) \\
11.7 \pm 0.410 \\
(21)\end{array}$ & $\begin{array}{c}44.78 \pm 0.93 \\
(10) \\
45.06 \pm 1.09 \\
(9)\end{array}$ & $\begin{array}{c}22.56 \pm 0.311 \\
(10) \\
30.35 \pm 0.307 \ddagger \\
(9)\end{array}$ \\
\hline $\begin{array}{l}\text { Potassium } \\
\qquad(\mathrm{meq} / 100 \mathrm{~g})\end{array}$ & $\mathrm{E}$ & $\begin{array}{c}16.1 \pm 1.060 \\
(10) \\
17.7 \pm 0.860 \\
(9)\end{array}$ & $\begin{array}{c}36.1 \pm 0.687 \\
(28) \\
34.8 \pm 0.539 \\
(21)\end{array}$ & $\begin{array}{c}13.84 \pm 1.05 \\
(10) \\
11.21 \pm 0.65^{*} \\
(9)\end{array}$ & $\begin{array}{c}4.30 \pm 0.188 \\
(10) \\
3.45 \pm 0.313^{*} \\
(9)\end{array}$ \\
\hline
\end{tabular}

All measurements expressed in terms of fat-free dry weight. C, control, E, experimental (magnesium depleted); the numbers in parentheses indicate the number of chicks in each group. Mean differs from control :

${ }^{*} P<0.05$.

$\ddagger P<0.001$. 
TABLE III

Magnesium, Calcium, and Phosphorus in Total Carcass in Normal and Magnesium-Depleted Chicks

\begin{tabular}{lcc}
\hline & $\begin{array}{c}\text { Control } \\
(\mathbf{n}=7)\end{array}$ & $\begin{array}{c}\text { Magnesium } \\
\text { depletion } \\
(\mathbf{n}=7)\end{array}$ \\
\hline $\begin{array}{l}\text { Magnesium } \\
\text { Total (mg/chick) }\end{array}$ & $31 \pm 2.7$ & $17 \pm 0.7^{*}$ \\
Conc. (mg/g body wt) & $0.252 \pm 0.022$ & $0.168 \pm 0.013 \ddagger$ \\
Calcium & & \\
$\quad$ Total (mg/chick) & $654 \pm 61$ & $763 \pm 26$ \\
Conc. (mg/g body wt) & $5.40 \pm 0.54$ & $7.6 \pm 0.44 \ddagger$ \\
Phosphorus & & \\
Total (mg/chick) & $590 \pm 43$ & $610 \pm 25$ \\
Conc. (mg/g body wt) & $4.8 \pm 0.4$ & $6.1 \pm 0.4 \S$ \\
\hline
\end{tabular}

Values are presented as mean $\pm \mathrm{SE}$; differ from control:

$*_{i} P<0.001$.

$\ddagger P<0.01$.

$\S P<0.05$.

significantly greater in the depleted chicks than in controls (Table III).

Table IV depicts the results of intestinal calcium transport, studied in vitro. The rates of flux, $J m \rightarrow s$ and $J_{\mathcal{S}} \rightarrow m$, were both greater in the chicks with magnesium deficiency than in controls. However, net influx, $(J m \rightarrow s)-(J s \rightarrow m)$ was considerably greater in the magnesium-depleted birds.

Large dietary supplements of either calcium or vitamin $D_{3}$ failed to restore serum calcium to normal in the magnesium-depleted cockerels (Table V). However, the serum calcium was slightly but significantly increased in magnesium-depleted chicks receiving diets containing either 3.6 or $12 \%$ calcium or vitamin $D_{3}, 800,000 \mathrm{IU} / \mathrm{kg}$ diet. Dietary supplementation with $0.060 \%$ magnesium for 3 days restored both serum magnesium and calcium to normal in chicks with either 1.2 or $0 \%$ calcium in the diet (Table VI). The addition of $0.010 \%$ magnesium to the diet for a similar period resulted in a smaller but significant increment in the serum concentrations of both magnesium and calcium.

The results from experiments with the injections of PTE to normal, magnesium-depleted and -repleted chicks are summarized in Table VII. The injection of PTE, in doses as high as $200 \mathrm{U}$, failed to produce a calcemic response in the magnesium-depleted birds, while PTE produced a significant increase in serum calcium in normal chicks and in previously depleted chicks which had received the normal magnesium diet for either 3 or 8 days.

At 21 days of age, the chicks receiving the low magnesium diet were noticeably smaller, and their long bones were shorter than those in chicks receiving the normal magnesium diet throughout. However, the thickness of cortical bone was visibly greater in the magnesium-depleted birds (Fig. 4). Moreover, the dried shafts of the shorter femurs from the magnesium-depleted birds had weights which were equal to or greater than those of the normal chicks. The results of microradiographic studies carried out in magnesium-depleted chicks and in previously depleted chicks which had received the $0.060 \%$ magnesium diet for 3 days are given in Table VIII. The cortical thickness, evaluated both in longitudinal sections of the distal femur and in a cross-section of the mid-shaft of the femur, was significantly less in the magnesium-repleted than in magnesium-depleted chicks; examples of microradiographs of cross-sections of femurs from representative chicks from each group are shown in Fig. 5. The percent of endosteal surface showing resorption was significantly greater in the magnesium-depleted birds. Histologic evaluation of undecalcified sections of bone in the area of the epiphyseal plates revealed increased quantities of noncalcified osteoid tissue. There were no histologic abnormalities in the kidneys from magnesium-depleted chicks. The parathyroid glands were similar in size and histologic appearance in chicks receiving normal or magnesium-restricted diets.

\section{DISCUSSION}

The results of the present study show that marked hypocalcemia develops rapidly with magnesium depletion in the growing chick. The data provide strong evidence that the reduction of plasma calcium with magnesium depletion was not due to impaired or reduced intestinal absorption of calcium. Thus, there was increased rather than diminished net intestinal calcium transport; second, there was restoration of plasma calcium to normal with dietary magnesium supplements even though calcium was absent from the diet. Third, the concentrations

TABLE IV

Effect of Magnesium Depletion on Net Intestinal Calcium Content Measured In Vitro

\begin{tabular}{lccccc}
\hline \multirow{2}{*}{$\begin{array}{c}\text { Experimental } \\
\text { group }\end{array}$} & \multicolumn{5}{c}{ Calcium flux* } \\
\cline { 2 - 6 } & $J m \rightarrow s$ & & $J s \rightarrow m$ & $J_{\text {netf }}$ \\
\hline & & & $n m o l / h / \mathrm{cm}^{2}$ \\
Control & $1.53 \pm 0.42$ & $(9)$ & $0.24 \pm 0.07$ & (5) & 1.29 \\
$\begin{array}{c}\text { Magnesium } \\
\text { depletion }\end{array}$ & $4.97 \pm 1.39 \S$ & (9) & $0.94 \pm 0.24 \|$ & (5) & 4.03 \\
\hline
\end{tabular}

Number in parenthesis indicates number of chicks in each group.

* All data are mean $\pm \mathrm{SE}$.

$\ddagger J_{\text {net }}=(J m \rightarrow s)-(J s \rightarrow m)$. Values in magnesium-depleted chicks differ from control:

$\S P<0.01$.

$\| P<0.001$ 
TABLE V

Effects of Variation in Dietary Content of Magnesium, Calcium, and Cholecalciferol during Days 19-21 on Serum Calcium and Magnesium in Previously Magnesium-Depleted Chicks

\begin{tabular}{|c|c|c|c|c|c|c|}
\hline & \multicolumn{3}{|c|}{ Dietary content (days 19-21) } & \multirow{2}{*}{$\begin{array}{l}\text { No. } \\
\text { chicks }\end{array}$} & \multicolumn{2}{|c|}{ Serum* } \\
\hline & Magnesium & Calcium & Vitamin $D_{3}$ & & Magnesium & Calcium \\
\hline & $\%$ & $\%$ & $I U / \mathrm{kg}$ & & \multicolumn{2}{|c|}{$\mathrm{mg} / 100 \mathrm{ml}$} \\
\hline A & 0.060 & 1.2 & 800 & 8 & $1.47 \pm 0.086$ & $9.74 \pm 0.46$ \\
\hline B & 0 & 1.2 & 800 & 6 & $0.65 \pm 0.061$ & $5.38 \pm 0.34$ \\
\hline $\mathrm{C}$ & 0 & 3.6 & 800 & 7 & $0.59 \pm 0.046$ & $7.44 \pm 0.31$ \\
\hline D & 0 & 12.0 & 800 & 8 & $0.70 \pm 0.043$ & $7.70 \pm 0.39$ \\
\hline $\mathrm{E}$ & 0 & 1.2 & 80,000 & 8 & $0.51 \pm 0.022$ & $5.90 \pm 0.34$ \\
\hline $\mathrm{F}$ & 0 & 1.2 & 800,000 & 8 & $0.74 \pm 0.026$ & $7.75 \pm 0.36$ \\
\hline
\end{tabular}

* All data are mean $\pm \mathrm{SE}$; all chicks received the usual magnesium depletion diet for 18 days after hatching. There were significant differences in serum calcium levels between group $\mathrm{A}$ vs. $\mathrm{D}$ and $\mathrm{F}, P<0.01$ and vs. $\mathrm{B}$ and $\mathrm{E}, P<0.001$; group $\mathrm{B}$ vs. $\mathrm{C}$ and $\mathrm{D}, P<0.001$; and group $\mathrm{E}$ vs. $\mathrm{F}, P<0.001$.

of calcium and phosphate were increased in the carcasses of the magnesium-depleted chicks. This occurred in the face of slightly reduced intake of food and is best explained by enhanced net absorption. The small but significant increase in serum calcium level following the 3to 10 -fold augmentation of dietary calcium indicates that additional calcium can be absorbed. Increased intestinal calcium transport in vitro has also been found in the magnesium-depleted rat (22-25) and calf (6).

Increased content of calcium and even overt calcification of soft tissues have been reported in the magnesiumdepleted rat (26-28), but this has generally been associated with increased rather than low values of blood calcium. The results of present studies which show no in-

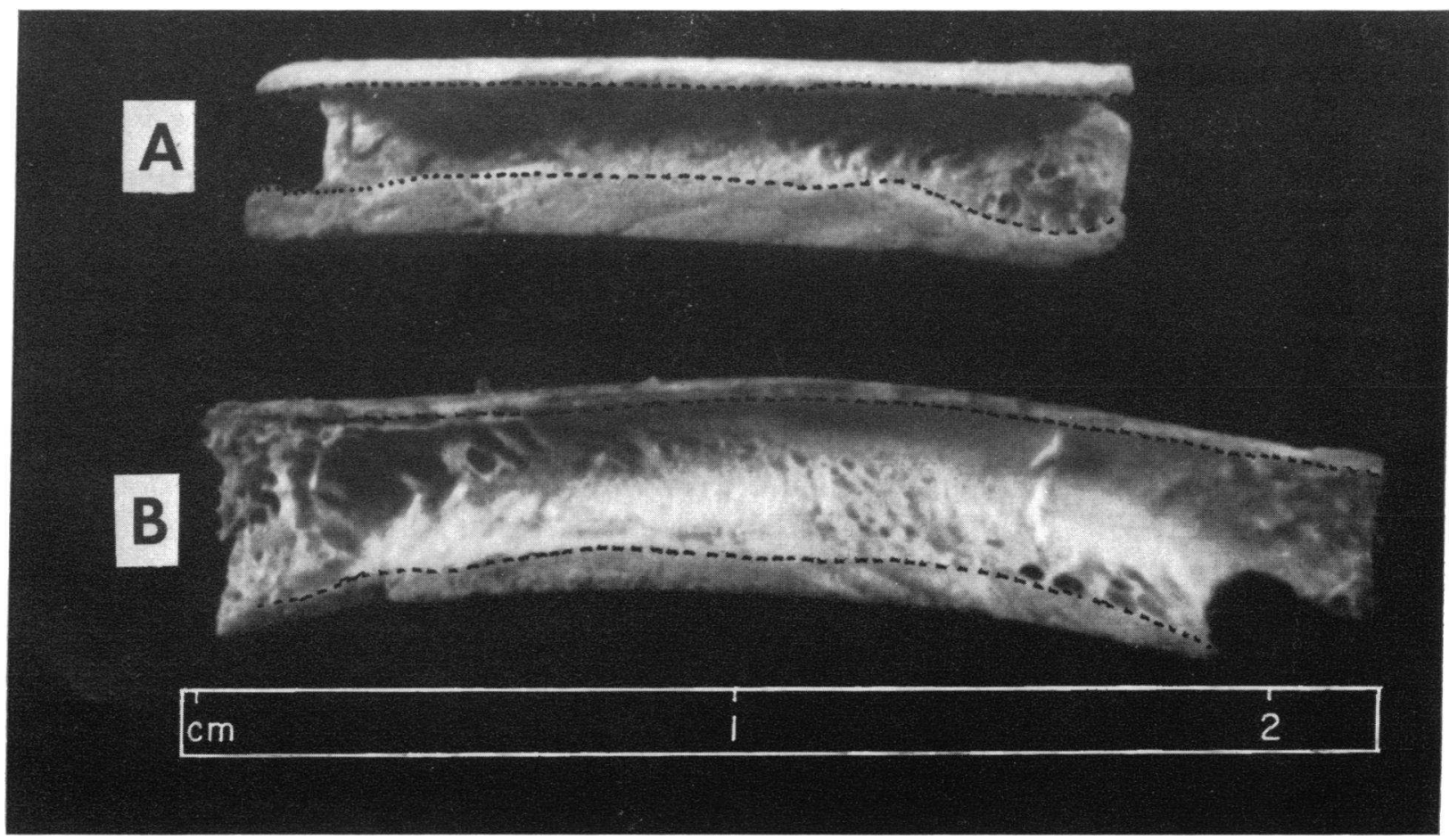

FIGURE 4 Gross appearance of femurs, cut longitudinally, from a magnesium-depleted chick $(A)$ and from a chick of the same age receiving a normal diet $(0.060 \%$ magnesium $), B$. The interrupted lines are drawn to show the thickness of cortical bone. The weights of the two dried fragments of bone are 102 and $96 \mathrm{mg}$, above and below, respectively. 
TABLE VI

Effects of Varying Intakes of Magnesium and Calcium during Magnesium Repletion of Magnesium-Depleted Chicks

\begin{tabular}{|c|c|c|c|c|c|}
\hline & \multicolumn{2}{|c|}{ Repletion diet } & \multirow{2}{*}{$\begin{array}{l}\text { No. } \\
\text { chicks }\end{array}$} & \multicolumn{2}{|c|}{ Serum* } \\
\hline & Calcium & Magnesium & & Magnesium & Calcium \\
\hline & \multicolumn{2}{|l|}{$\%$} & & \multicolumn{2}{|c|}{$\mathrm{mg} / 100 \mathrm{ml}$} \\
\hline A & 1.2 & 0 & 19 & $0.37 \pm 0.029$ & $5.76 \pm 0.21$ \\
\hline B & 1.2 & 0.010 & 14 & $0.55 \pm 0.043$ & $8.72 \pm 0.5$ \\
\hline C & 1.2 & 0.060 & 10 & $2.17 \pm 0.066$ & $11.72 \pm 0.21$ \\
\hline $\mathrm{D}$ & 0 & 0 & 14 & $0.57 \pm 0.039 \ddagger$ & $5.49 \pm 0.1$ \\
\hline $\mathrm{E}$ & 0 & 0.010 & 15 & $1.05 \pm 0.051 \ddagger$ & $8.79 \pm 0.5$ \\
\hline $\mathrm{F}$ & 0 & 0.060 & 10 & $2.32 \pm 0.060$ & $11.28 \pm 0.1$ \\
\hline
\end{tabular}

* All data are mean $\pm \mathrm{SE}$; all birds received the low magnesium diets described in the Methods section; on days 19, 20, and 21, the salt mixture of the diet contained varying amounts of calcium and magnesium as noted above.

† Serum magnesium levels significantly higher, group D vs. A, and group $\mathrm{E}$ vs. B, $P<0.001$.

crease in soft tissue calcium content militate against the possibility that a propensity for calcium movement from plasma into soft tissues could have accounted for the hypocalcemia.

An increase in serum phosphorus level can cause a fall in serum calcium level, and the hyperphosphatemia observed in the magnesium-depleted chick could contribute to the degree of hypocalcemia. However, since significant hypocalcemia developed in magnesium-depleted birds which received restricted phosphate diets and were not hyperphosphatemic, an elevated serum phosphorus is clearly not the major factor responsible for the hypocalcemia in this model of magnesium depletion.

Failure of production or release of parathyroid hormone $(\mathrm{PTH})$ by the parathyroid glands could be re-

TABLE VII

Effect of Parathyroid Extract on Serum Calcium in Magnesium-Depleted Chicks

\begin{tabular}{|c|c|c|c|c|c|}
\hline \multirow[b]{2}{*}{ Group } & \multirow{2}{*}{$\begin{array}{l}\text { No. } \\
\text { chicks }\end{array}$} & \multirow{2}{*}{$\begin{array}{l}\text { Para- } \\
\text { thyroid } \\
\text { extract } \\
\text { dose }\end{array}$} & & \multicolumn{2}{|c|}{ Serum levels } \\
\hline & & & & Calcium & Magnesium \\
\hline & \multicolumn{3}{|c|}{$U /$ chick } & \multicolumn{2}{|c|}{$\mathrm{mg} / 100 \mathrm{ml}$} \\
\hline \multirow[t]{2}{*}{ Control } & 5 & 100 & Pre* & $9.35 \pm 0.28$ & $2.24 \pm 0.07$ \\
\hline & & & Post* & $11.16 \pm 0.77 \ddagger$ & $2.36 \pm 0.11$ \\
\hline \multirow[t]{4}{*}{ Depleted } & 7 & None & & $6.07 \pm 0.38$ & - \\
\hline & 6 & 50 & & $6.87 \pm 0.64$ & - \\
\hline & 8 & 100 & & $6.45 \pm 0.20$ & - \\
\hline & 6 & 200 & & $6.84 \pm 0.43$ & - \\
\hline \multicolumn{6}{|l|}{ Repleted } \\
\hline \multirow[t]{2}{*}{3 days } & 5 & 200 & Pre* & $8.45 \pm 0.21$ & - \\
\hline & & & Post* & $10.64 \pm 0.28 \S$ & - \\
\hline \multirow[t]{2}{*}{8 days } & 9 & 100 & Pre* & $10.49 \pm 0.22$ & $1.82 \pm 0.05$ \\
\hline & & & Post* & $12.91 \pm 0.43 \S$ & $2.32 \pm 0.06 \S$ \\
\hline
\end{tabular}

* Samples obtained before and $4 \mathrm{~h}$ after PTE injections in the same chicks. Post PTE values differ from pretreatment by paired analysis:

$\ddagger P<0.05$.

$\$ P<0.01$.
TABLE VIII

Cortical Thickness of Femora and Endosteal Bone Resportion in Magnesium Depletion

\begin{tabular}{cccc}
\hline & \multicolumn{2}{c}{ Cortical thickness } & \\
\cline { 2 - 3 } $\begin{array}{c}\text { Experimental } \\
\text { group }\end{array}$ & $\begin{array}{c}\text { Longitudinal } \\
\text { section, } \\
\text { distal femur }\end{array}$ & $\begin{array}{c}\text { Cross-section, } \\
\text { mid-femur }\end{array}$ & $\begin{array}{c}\text { Endosteal } \\
\text { resorption }\end{array}$ \\
\hline $\begin{array}{c}\text { Magnesium repletion } \\
\text { (7) }\end{array}$ & $570 \pm 54.6$ & $\%$ diameter & $\%$ total surface \\
$\begin{array}{c}\text { Magnesium depletion } \\
(8)\end{array}$ & $795 \pm 50.0^{*}$ & $30.0 \pm 1.68^{*}$ & $23.6 \pm 2.9 .3 \ddagger$
\end{tabular}

All data are expressed as mean $\pm \mathrm{SE}$; the numbers in parenthesis indicate the number of animals; values different from magnesium repletion:

$* P<0.01$.

$\ddagger P<0.001$.

sponsible for the hypocalcemia of magnesium depletion. Anast, Mohs, Kaplan, and Burns (29) and Suh, Tashjian, Matsuo, Parkinson, and Fraser (30) found reduced or undetectable levels of immunoreactive parathyroid hormone in the plasma of single hypocalcemic patients with magnesium depletion. Furthermore, data of Targovnik, Rodman, and Sherwood (31) revealed that the release of $\mathrm{PTH}$ from parathyroid glands in vitro was markedly reduced when the magnesium concentration in the medium was below $0.70 \mathrm{mg} / 100 \mathrm{ml}$. In contrast, other data suggest that a reduction in the serum level of magnesium may directly stimulate the secretion of parathyroid hormone: thus, perfusion of the parathyroid glands, in vitro, with blood containing a low concentration of magnesium causes release of $\mathrm{PTH}$ (32), and elevated levels of plasma $\mathrm{PTH}$ have been described in two patients with magnesium depletion $(13,33)$. Also, hyperplasia of the parathyroid glands has been described in magnesium-depleted calves (6). In our magnesiumdepleted chicks, there was no evidence of hyperplasia of the parathyroid glands; this observation contrasts to the marked enlargement of those glands observed in hypocalcemic, vitamin D-deficient chicks of the same age (34). In the present study, levels of circulating PTH were not measured, and the possibility that there was failure of parathyroid gland function in the magnesiumdepleted chicks cannot be excluded. However, the observations that large quantities of exogenous parathyroid extract produced no change in serum calcium in the magnesium-depleted birds indicate that even if there was functional failure of the parathyroid glands, it is not the only factor contributing to the hypocalcemia.

It is unlikely that excessive renal losses of calcium could lead to hypocalcemia during magnesium depletion since urinary excretion of calcium has been uniformly found to be low when such observations have been made in other species $(10,24,35,36)$. An increase in calci- 


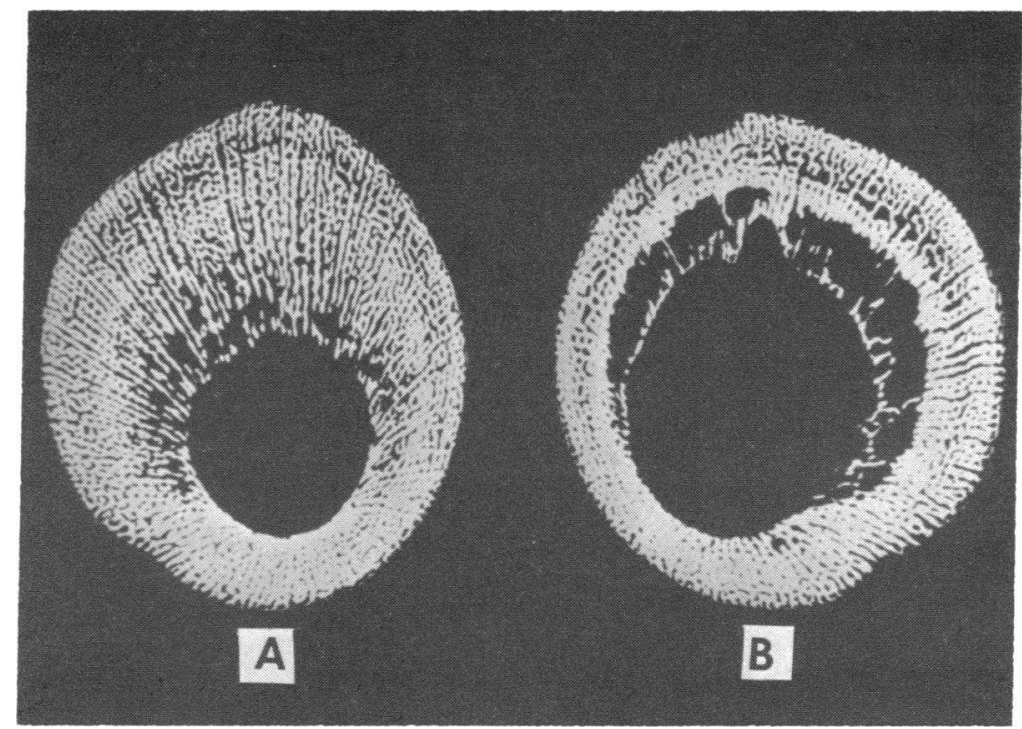

FIGLRE 5 Representative microradiographs of cross-sections from the mid-femurs of a magnesium-deficient chick $(A)$ and of a previously magnesium-deficient bird which was repleted with a normal diet for 3 days $(B)$.

tonin release, as a possible cause of hypocalcemia, is also remote. Elevated levels of magnesium may stimulate the release of calcitonin in the rat $(37)$; moreover, thyroidectomy has failed to alter the hypocalcemia seen with magnesium depletion $(7,9)$.

The present results do indicate that there is skeletal unresponsiveness to the action of parathyroid hormone in the magnesium-depleted chick, and this phenomenon may play some role in the development or propagation of hypocalcemia. Previous reports have shown that complete or partial resistance to the skeletal action of $\mathrm{PTH}$ may occur during magnesium depletion in various species, including the rat (1), human (11-14) and dog (8). Others have found normal action of PTH and have concluded that the hypocalcemia could not be due to abnormal skeletal response to the hormone $(2,7,9)$. Careful evaluation of these reports suggests that such discrepant results may be related to the degree of magnesium depletion $(1,13)$.

The factors responsible for a reduced calcemic response to parathyroid extract in magnesium depletion are not known. Theoretically, such an abnormality could result from a deficiency of vitamin $\mathrm{D}$ or failure to activate the vitamin. Available data do not support the existence of an abnormality of vitamin $\mathrm{D}$ action or metabolism in magnesium deficiency. Thus, intestinal calcium transport was increased rather than reduced during magnesium deficiency, the percent bone ash was not reduced, and serum phosphorus was elevated or normal rather than reduced. Metabolic studies of $\left[{ }^{3} \mathrm{H}\right]$ cholecalciferol in magnesium-deficient chicks indicate enhanced localiza- tion of 1,25-dihydroxycholecalciferol in the one target tissue examined (e.g., the intestine) (38).

It was generally believed that a permissive role of vitamin $\mathrm{D}$ is required before $\mathrm{PTH}$ will produce a calcemic effect $(39,40)$. More recently, however, it has been shown that hypocalcemia may prevent a skeletal response to PTE in rats (41) and in dogs (42), and this abnormality has been attributed to the presence of excess osteoid tissue (41). The appearance of excess osteoid in the magnesium-depleted chicks is probably due to hypocalcemia, and the presence of such osteoid may be the major factor leading to unresponsiveness to PTE (42).

Magnesium depletion per se may directly affect bone metabolism resulting in a relative reduction in release of calcium from the mineral phase of bone; such an effect may be the prime factor responsible for the hypocalcemia. It was suggested by Neuman and Neuman (43) that magnesium may exchange for calcium on the surface of bone mineral, and MacManus and Heaton (44) and Pak and Diller (45) have provided evidence in support of this. MacManus and Heaton found that the release of radiocalcium from bone due both to physicochemical processes and to metabolic activity was reduced in bones from magnesium deficient rats (44). Also, Raisz and Niemann, studying tissue cultures of bone, found that the calcium release which is stimulated by $\mathrm{PTH}$ was reduced in the presence of a low magnesium concentration (46). Elin, Armstrong, and Singer found an increased percentage of calcium in bone ash of hypocalcemic, magnesium-deficient rats (47). These observations and the results of the present study, which show increased cor- 
tical thickness of bone and reduced resorptive surfaces in association with hypocalcemia and a rapid correction of these abnormalities following magnesium repletion, point to the prominent role of altered skeletal dynamics or solubility of bone crystals in the genesis of hypocalcemia during magnesium depletion.

A rational synthesis of data from various laboratories, which suggest different mechanisms for the hypocalcemia of magnesium depletion, is possible, but it requires a multifactorial pathogenesis. A reduction of blood magnesium could stimulate $\mathrm{PTH}$ release, while more protracted depletion of magnesium may impair the production of PTH (29). When magnesium depletion is not extremely severe, there may be normal or only slightly reduced calcemic response to the administration of PTE. A reduction of blood calcium under these circumstances indicates that resistance to the action of PTH is not a sine qua non for the genesis of hypocalcemia. Serum calcium may be lowered as a result of failure of production or release of endogenous PTH, an alteration in the exchange of calcium between extracellular fluid and bone which favors net movement into the skeleton, or both factors. More severe or more profound magnesium deficiency, as probably exists in the chicks of the present study, may lead to a reduced or absent skeletal response to PTE. The presence of excess quantities of uncalcified osteoid tissue most likely due to hypocalcemia per se is probably the major factor contributing to the diminished calcemic response to PTE (42); this could exaggerate the degree of hypocalcemia. Differences between species and variation depending on the age of experimental animals might lead to different results; however, MacManus, Heaton, and Lucas $(1,48)$ found a variation in the calcemic response to PTE in the same species depending on the degree of magnesium depletion.

The increased plasma uric acid level in the magnesiumdeficient chick suggests decreased renal function, an abnormality described with magnesium depletion in the guinea pig (49) and rat $(50,51)$, although nephrocalcinosis associated with hypercalcemia may be responsible in the latter species. In the chick, uric acid levels were elevated in the face of normal renal histology and no increase in tissue content of calcium. The increased plasma phosphorus levels, observed with magnesium deficiency, may be related to reduced renal function, although chicks with equally elevated uric acid levels following partial destruction of renal tissue did not have hyperphosphatemia (18). The increase in plasma phosphorus might be due to the hypocalcemia per se (52), or it might be a manifestation of failure of parathyroid function. The alterations in plasma concentrations of sodium and potassium observed in the magnesium-deficient chicks are greater than those generally reported in other species; MacIntyre and Davidson found increased serum sodium levels in the magnesium-depleted rat (51), and decreased tissue or plasma potassium levels have been described in several species, including man (10) and the rat $(51,28)$. Observations in man suggest that continued renal excretion of potassium contributes to the development of potassium depletion (10). From experiments carried out in the rat, Welt found that magnesium deficiency causes a reduced activity of $\mathrm{Na}-\mathrm{K}-\mathrm{Mg}$-ATP-ase in the erythrocyte, and he postulated that this accounts for altered sodium and potassium in the red cell (50). It has been suggested that a similar effect may occur in other tissues (47).

\section{ACKNOWLEDGMENTS}

Technical support was provided by John Steppe, Ernest Tallos, Susan Bashner, Thomas Rejel, Burton Schatz, and William Van Buren. Secretarial assistance was provided by Mrs. Catherine Hoyt. Dr. Jerome Wollman kindly prepared the histologic sections, and we are grateful to Doctors R. R. MacGregor, J. W. Hamilton, and D. V. Cohn of the Kansas City VA Hospital, Kansas City, Mo., who instructed us in the techniques for parathyroidectomy in the chick.

This work was supported in part by a grant from the Southern California Kidney Foundation and U. S. Public Health Service Training Grant AM 5383.

\section{REFERENCES}

1. MacManus, J., F. W. Heaton, and P. W. Lucas. 1971. Decreased response to parathyroid hormone in magnesium deficiency. J. Endocrinol. 49: 253.

2. Hahn, T. J., L. R. Chase, and L. V. Avioli. 1972. Effect of magnesium depletion on responsiveness to parathyroid hormone in parathyroidectomized rats. $J$. Clin. Invest. $51: 886$.

3. L'Estrange, J. L., and R. F. Axford. 1964. A study of magnesium and calcium metabolism in lactating ewes fed a semipurified diet low in magnesium. J. Agric. Sci. $62: 353$.

4. Miller, E. R., D. E. Ullrey, C. L. Zutaut, B. V. Baltzer, D. A. Schmidt, J. A. Hoefer, and R. W. Luecke. 1965. Magnesium requirement of the baby pig. J. Nutr. 85: 13.

5. Smith, R. H. 1961. Importance of magnesium in the control of plasma calcium in the cali. Nature (Lond.). $191: 181$.

6. Larvor, P., A. Girard, M. Brochart, A. Parodi, and J. Sevestra. 1964. Etude de la casence experimentale en magnesium chez le veau. I. Observations cliniques, biochemiques, et anatomo-pathologiques. Ann. Biol. Anim. Biochim. Biophys. $4: 345$.

7. Suh, S. M., A. Csima, and D. Fraser. 1971. Pathogenesis of hypocalcemia in magnesium depletion. J. Clin. Invest. 50: 2668.

8. Levi, J., F. Llach, S. G. Massry, and C. R. Kleeman. 1972. Effect of magnesium depletion on serum calcium and on the response of bone and kidney to parathyroid hormone. Clin. Res. 20: 192.

9. Dunn, M. J. 1971. Magnesium depletion in rhesus monkey: induction of magnesium-dependent hypocalcemia. Clin. Sci. 41: 333 . 
10. Shils, M. E. 1969. Experimental magnesium depletion. Medicine (Baltimore). 48: 61.

11. Estep, H., W. A. Shaw, C. Waltington, R. Hobe, W. Holland, and St. G. Tucker. 1969. Hypocalcemia due to hypomagnesemia and reversible parathyroid hormone unresponsiveness. J. Clin. Endocrinol. 29: 842.

12. Muldowney, F. P., T. J. McKenna, L. H. Kyle, R. Freaney, and M. Swan. 1970. Parathormone-like effect of magnesium replenishment in steatorrhea. N. Engl. J. Med. 282: 61 .

13. Connor, T. B., P. Toskes, J. Mahaffey, L. G. Martin, J. B. Williams, and M. Walser. 1972. Parathyroid function during chronic magnesium deficiency. J. Hopkins Med. J. $131: 100$.

14. Woodward, J. C., P. D. Webster, and A. A. Carr. 1972. Primary hypomagnesemia with secondary hypocalcemia, diarrhea and insensitivity to parathyroid hormone. Dig. Dis. $17: 612$

15. Polin, D., P. D. Sturkie, and W. Hunsaker. 1957. The blood calcium response of the chicken to parathyroid extract. Endocrinology. $60: 1$.

16. Fox, M. R. S., and G. M. Briggs. 1960. Salt mixtures for purified-type diets. III. An improved salt mixture for chickens. J. Nutr. $72: 243$.

17. Almquist, H. J. 1942. Magnesium requirement of the chick. Proc. Soc. Exp. Biol. Med. 49: 544.

18. Hartenbower, D. L., and J. W. Coburn. 1972. A model of renal insufficiency in the chick. Lab. Anim. Sci. 22: 258.

19. Adams, T. H., and A. W. Norman. 1970. Studies on the mechanism of action of calciferol. I. Basic parameters of vitamin D mediated calcium transport. $J$. Biol. Chem. 245 : 4421.

20. Jowsey, J. 1966. Quantitative microradiography: a new approach in the evaluation of metabolic bone disease. Am. J. Med. 40: 485.

21. Coburn, J. W., and S. G. Massry. 1970. Changes in serum and urinary calcium during phosphate depletion: studies on mechanisms. J. Clin. Invest. 49: 1073.

22. Kessner, D. M., and F. H. Epstein. 1966. Effect of magnesium deficiency on gastrointestinal transfer of calcium. Proc. Soc. Exp. Biol. Med. 122: 721.

23. Morehead, R. M., Jr., and D. M. Kessner. 1969. Effects of $\mathrm{Mg}$ deficiency and parathyroidectomy on gastrointestinal $\mathrm{Ca}$ transport in the rat. Am. J. Physiol. 217: 1608.

24. Alcock, N., and I. MacIntyre. 1962. Interrelation of calcium and magnesium absorption. Clin. Sci. 22: 185.

25. Lifshitz, F., H. C. Harrison, and H. E. Harrison. 1967. Intestinal transport of calcium and phosphate in experimental magnesium deficiency. Proc. Soc. Exp. Biol. Med. $125: 19$.

26. Chutkow, J. G. 1965. Studies on the metabolism of magnesium in the magnesium deficient rat. J. Lab. Clin. Med. 65: 912.

27. Ko, K. W., F. X Fellers, and J. M. Craig. 1962. Observations on magnesium deficiency on the rat. Lab. Invest. $11: 294$.

28. Whang, R., and L. G. Welt. 1963. Observations on experimental magnesium depletion. J. Clin. Invest. 42: 305.

29. Anast, C. S., J. M. Mohs, S. L. Kaplan, and T. W. Burns. 1972. Evidence for parathyroid failure in magnesium deficiency. Science (Wash. D. C.). 177: 606.

30. Suh, S. M., A. H. Tashjian, N. Matsuo, D. K. Parkinson, and D. Fraser. 1973. Pathogenesis of hypocalcemia in primary hypomagnesemia: normal end-organ responsiveness to parathyroid hormone, impaired parathyroid gland function. J. Clin. Invest. 52: 153.

31. Targovnik, J. H., J. S. Rodman, and L. M. Sherwood. 1971. Regulation of parathyroid hormone secretion in vitro: quantitative aspects of calcium and magnesium ion control. Endocrinology. 88: 1477.

32. Buckle, R. M., A. D. Care, C. W. Cooper, and H. J. Gitelman. 1968. The influence of plasma magnesium concentration on parathyroid hormone secretion. $J$. Endocrinol. 42 : 529 .

33. Sherwood, L. M. 1970. Magnesium ion and parathyroid function. N. Engl. J. Med. 282: 752.

34. MacGregor, R. R., L. L. H. Chu, J. W. Hamilton, and D. V. Cohn. 1973. Partial purification of parathyroid hormone from chicken parathyroid glands. Endocrinology. $92: 1312$.

35. Smith, W. O., D. J. Baxter, A. Lindner, and H. E. Ginn. 1962. Effect of magnesium depletion on renal function in the rat. J. Lab. Clin. Med. 59: 211.

36. Heaton, F. W. 1965. The parathyroid glands and magnesium metabolism in the rat. Clin. Sci. 28: 543.

37. Radde, I. C., E. R. Wittermann, and S. Pensuwan. 1968. Effect of thyroid and parathyroid on hypocalcemia occurring after a magnesium load. Endocrinology. $83: 1285$.

38. Coburn, J. W., C. R. Reddy, A. S. Brickman, D. L Hartenbower, R. M. Friedler, and A. W. Norman. 1973. Vitamin D metabolism in magnesium deficiency. Fed. Proc. 32 : 918.

39. Harrison, H. C., H. E. Harrison, and E. A. Park 1958. Vitamin D and citrate metabolism: effect of vita$\min \mathrm{D}$ in rats fed diets adequate in both calcium and phosphorus. Am. J. Physiol. $192: 432$.

40. Rasmussen, H., H. DeLuca, C. Arnaud, C. Hawker, and M. Van Stedingk. 1963. The relationship between vitamin $\mathrm{D}$ and parathyroid hormone. J. Clin. Invest. 42: 1940.

41. Au, W. Y. W., and L. G. Raisz. 1967. Restoration of parathyroid responsiveness in vitamin $D$-deficient rats by parenteral calcium on dietary lactose. J. Clin. Invest. $46: 1572$.

42. Jowsey, J. 1972. Calcium release from the skeletons of rachitic puppies. J. Clin. Invest. 51: 9.

43. Neuman, W. S., and M. W. Neuman. 1958. The Chemical Dynamics of Bone Mineral. University of Chicago Press, Chicago, Ill. 55.

44. MacManus, J., and F. W. Heaton. 1970. The influence of magnesium on calcium release from bone in vitro. Biochem. Biophys. Acta. 215: 260.

45. Pak, C. Y. C., and E. C. Diller. 1969. Ionic interaction with bone mineral. V. Effect of magnesium, citrate, fluoride and sulfate on the solubility, dissolution and growth of bone mineral. Calcif. Tissue Res. 4: 69.

46. Raisz, L. G., and I. Niemann. 1969. Effect of phosphate, calcium, and magnesium on bone resorption and hormonal responses in tissue culture. Endocrinology. $85: 446$.

47. Elin, R. J., W. D. Armstrong, and L. Singer. 1971 Body fluid electrolyte composition of chronically magnesium-deficient and control rats. Am. J. Physiol. 220: 543.

48. MacManus, J., and F. W. Heaton. 1969. The effect of magnesium deficiency on calcium homeostasis in the rat. Clin. Sci. 36: 297.

49. Morris, E. R., and B. L. O'Dell. 1969. Effect of magnesium deficiency in guinea pigs on kidney function 
and plasma ultrafiltrable ions. Proc. Soc. Exp. Biol. Med. $132: 105$.

50. Welt, L. G. 1964. Experimental magnesium depletion. Yale J. Biol. Med. 36 : 325

51. MacIntyre, I., and D. Davidson. 1968. The production of secondary potassium depletion, sodium retention, nephrocalcinosis and hypercalcemia by magnesium depletion. Biochem. J. 70 : 456.

52. Eisenberg, E. 1965. Effects of serum calcium level and parathyroid extracts on phosphate and calcium excretion in hypoparathyroid patients. J. Clin. Invest. $44: 942$. 